\section{Problems delay emergence of Moscow research centre}

Moscow. Glenn Schweitzer does not have a permanent office. He cannot afford the cost of a modern peer-review system. And he is International Research and Technology Centre in Moscow, that does not yet exist.

But Schweitzer, on a two-year leave of absence from the US National Academy of Sciences, has access to something that hundreds of Russian scientists from the former Soviet defence establishment would like a share of: $\$ 70$ million pledged by industrial nations to help them transfer their skills to the civilian sector.

The centre that presidents Boris Yeltsin of Russia and George Bush of the United States agreed to create six months ago is expected to open by the autumn. Its purpose is to support Soviet scientists previously engaged in research on weapons of mass destruction, including chemical and bacteriological as well as nuclear weapons. The final obstacles are technical ones relating to the translation of documents, says Schweitzer, says he sees "no reason for further delay".

The centre will not be a laboratory in its own right, but rather a clearinghouse to match worthy ideas with sources willing to pay for them. Most of the work is expected to be in weapons disarmament, environmental cleanup, energy development and conservation and the transition to a market economy, although some will focus on fundamental research.

Proposals will be reviewed first by scientists from around the world to decide their technical merit, then judged by a board of tributing countries. Individual proposals will then be paired with sources of funding, both public and private. Russia will have the right to reject any project.

The first recipients are expected to be scientists from the formerly secret military research centres at Arzamas and Chelyabinsk. Negotiations are also under way with Ukrainian specialists in ballistic missiles and, in Khazakstan, with specialists from the town of Kurchatov (near the Semipalatinsk proving ground) engaged in nuclear testing. A sister centre is being set up in Kiev, for Ukrainian weapons scientists, with $\$ 12$ million in Western funding.

Schweitzer arrived in Moscow last month,

\section{Correction}

A photograph in last week's issue of Nature $(358,180 ; 1992)$ identified as being of D. Allan Bromley, US presidential science adviser, was in fact a picture of John Rollwagen, chairman of Cray Research Inc. executive director of an institution, the and Russian academician Eugene Velikhov science administrators from each of the con- hoping to occupy space in a science park being built at Moscow State University. But work on the new park is progressing more slowly than planned, forcing Russian authorities to continue their search for a permanent home in Moscow for a staff that is expected to number two dozen before the end of the year.

The original plan was for the centre to be at Troitsk, a small town near Moscow well equipped with communications, hotels and even schools for the children of foreign staff. But Russian military administrators, attracted to the centre by a decision that half of their salary will be paid in hard currency, apparently wanted a site closer to home.

Another logistical hurdle is the difficulty of conducting a rigorous peer review of the proposals that are expected to pour into the centre. "Communications links are still a major problem", Schweitzer says. E-mail cannot accommodate all the graphic elements of a typical proposals, and "faxing to countries around the world is prohibitively expensive".

Even more troubling is that few of the Russian scientists, having worked in secrecy, are known to their international collleagues. "We should get good reviews of the potential payoff and technical merits of the proposal", says Schweitzer, "but it'll be hard for reviewers to assess the technical skills of the people involved if nobody knows their work". One safeguard is careful monitoring of work in progress by staff at the centre, as well as by Western partners.

Not everybody shares the enthusiasm of the founders for the new centre and their confidence in the ability of government bodies to adapt to new conditions. George Soros, who has promised to supplement the salaries of researchers working through the centre by $\$ 100$ a month (see Nature 357, $431 ; 1992$ ), says that "US bureaucrats are better at turning other people's bucks into their own limousines". And Maxim FrankKamenetskii, a prominent researcher at the Institute of Molecular Genetics of the Russian Academy of Sciences, believes the venture "is doomed to fail" because the historically high barriers to the flow of information within the former Soviet Union will prevent people from being able to judge their colleagues' work accurately.

Vladimir Pokrovsky

\section{Anything left for civilian science?}

Washington. The United States has pledged $\$ 35$ million to two research centres in Moscow and Kiev intended to give former Soviet weapons scientists the chance to make peace, not war. But getting anything close to that amount for civilian scientists, who need support just as badly as their military counterparts, has proved much more difficult. D. Allan Bromley, science adviser to President George

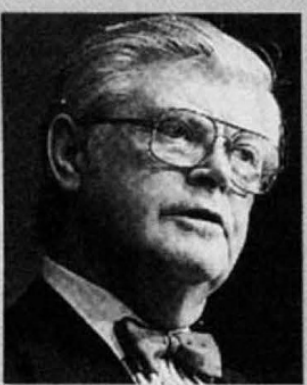

D. Allan Bromley Bush, has been trying to persuade the US State Department and the Agency for International Development (AID) to reallocate some of AID's current budget, in the fiscal year ending 30 September, for direct aid to scientists in the former Soviet Union. AID is spending $\$ 235$ million this year to heip Russia dismantle and safeguard its nuclear arsenal, including $\$ 150$ million in new money from a supplementary appropriation passed earlier this year.

AID has given $\$ 2$ million to the National Academy of Sciences to pay for as many as 150 Russians to come to the United States and work temporarily with US researchers. Bromley wants another $\$ 25$ million for the National Science Foundation (NSF) and the National Institutes of Health (NIH), the two federal agencies in the best position to coordinate such a programme of small grants. NIH has spent about $\$ 3$ million this year on several programmes to help those in the former Soviet Union, the most popular being long-term visits to NIH laboratories and supplementary grants to US scientists working with Russian scientists. NSF has spent slightly more than $\$ 2$ million this year on similar cooperative research projects. The agencies raised the money by taxing other programmes.

But Bromley's plea, taken from a recommendation made by experts assembled by the National Academy of Sciences, has apparently fallen on deaf ears within the Bush administration. "He struck out", says one NSF official. An NIH administrator is a bit kinder. "So far that idea has not borne fruit", he says. "It would be pretty hard to do anything like that this late in the fiscal year."

But Bromley has not given up hope. Civilian scientists in the former Soviet Union "have an immediate need" for US funding, he says, and "we don't want to wait for complex mechanisms that will take years to work out. I'm still trying to get them money now, in FY [fiscal year] 92 dollars."

Jeffrey Mervis 